\title{
Non-Linear Dynamics of Macroeconomic Variables: The Case of Greece
}

\author{
By Sophia Kassapi ${ }^{1}$
}

\begin{abstract}
This paper is part of an ongoing doctoral dissertation. It examines the long run relationship between government spending on education, GDP growth and educational enrollments in all levels, for Greece in the years 1960-2012, leveling up to capture more complex dependent dynamics in time series. OECD Indicator A11 shows that, life satisfaction, civic engagement and health. are at the same level for adults with tertiary education and adults with upper secondary education for Greece. Having conducted Linear Granger tests, this study goes beyond, following the methodology of both non-parametric testing for asymptotic Granger causality in C, and non-parametric bootstrapped bidirectional Granger causality, an MS Dos application in C. We apply a new nonparametric test for Granger non-causality by Diks and Panchenko (2005, 2006) as well as the conventional linear Granger test on the time series. The secondary data used in this present study, have been processed through MATLAB interpolation function. There is a strong symmetric nonlinear causal relationship detected between government spending on education and enrollments in higher education, and vice versa, .An even stronger, both symmetric and asymmetric nonlinear relationship between higher education enrollments and Gdp growth is validated confirming a spectacular case of "adverse causality". Government spending in education is causally related with Gdp growth in a symmetric as much as an asymmetric nonlinear relationship. Also, lagged values of secondary enrollments are a major predictor of Gdp growth.
\end{abstract}

Keywords: Economic growth, Greek economy, Granger Causality, Non-linearity.

\section{Aims and Objectives of the Study}

At the dawn of the $21^{\text {st }}$ century, many important financial transitions were put into action for U.S. and Europe as well, one of them being the introduction of the new euro currency to the EU-member states. The need for better coordinated economic policies and monetary cooperation introduced the new currency not later than early 2002, earlier attempts are dated in the 1960s, while the idea for a European currency emerged back in 1929, in the League of Nations (LN). Meanwhile after 2002, the EU continued to grow large and accept new member states that would also be part of this coordinated European market, seeing it as their safety net. The outburst of the global recession in 2008 pulled euro zone into its first financial crisis. EU as a whole displayed negative growth for the three last quarters of 2008 and the first quarter of 2009 before returning to positive growth. Such a big crisis was feared that could break EU down. In order to avoid any domino effects where one member state could harm the other, all member states agreed to a joint action plan for the Euro zone to stabilize the European economy. Fearing a default for weak members such as Greece, they all agreed to set up a temporary bail out mechanism to overcome any financial solvency and credit limitations that could jeopardize the whole euro zone, aiming at restoring financial stability for Europe, and ensure further economic integration. This would be the start of a new era for Greece, that of austerity. Greece was proven a very special case, if not the weaker member state in terms of dealing with the onset of a 
recession. A major adjustment program was going to take place. The process of modernization of its economy and the continuation of the structural reforms dictated and financially supported by the EU/IMF/ECB (Troika), launched in 2010 would continue as announced in the summer of 2011, stating that this was the only way out. European leaders agreed to provide another financial support package to Greece. Greece committed to promote sustainable economic growth by applying all the needed fundamental fiscal and structural reforms (OECD, 2011), in return for their emergency loan that it received.

As a member state, Greece favored the same interest rates like the rest of the EU-countries. The eagerness though of the financial institutions to offer bigger purchasing power parity to people, even to those citizens who didn't qualify for those loans and all the lending criteria, made them forget the past stock market crash, and start all over setting up of another bubble. Immoderate consumption leading to high inflation rates and absolutely unorthodox growth was the new religion. The excess liquidity from the banks and the unstoppable demand for more products made the prices skyrocket. Apart from disposable goods, the biggest share of their borrowing capacity was devoted to real estate. This phenomenon was common for many countries around the globe. But when the 2008 financial crisis was outside the door, Greek economy couldn't fight against it, as it was already on the edge. The year of 2009 found the country with a fiscal deficit that had ballooned to over 15\% of GDP reflecting uncontained (public) spending, a collapse in tax revenues and the onset of a recession, while public debt reached 140\% of GDP in 2010 (OECD, 2011), the highest in the euro zone, not to mention the high private debt.

Ideally speaking, none of these adjustments would have been necessary if this country was an island, a rather remote and self catered one, away from all these regulating institutions. But in modern times no country can be that isolated. A country's national income, interest rates and market prices affect another country respectively. One country's economic growth or stagnation, contributes in the economic growth or stagnation of other countries, as the imported goods of a country, constitute the exported ones of the other. Mercantilism as a philosophy towards growth would never bear fruits for any country with a high public deficit in this global economy. Even if a country was to adopt such a policy, this could not last forever, and it would end with negative results. What fosters economic growth for the population is to raise their living conditions by having more products available, which would only take place by making use of each country's competitive advantage. All economies right now are in some way interdependent, and staying out is not an option, because any extreme decision in one part of this world, affects the lives of the citizens in another country in some other part, not knowing exactly how but definitely provoking a commercial war.

If we think of a country's economy as an engine, then it is easy to predict that the outcome depends severely on what goes in that engine, the productive elements. The most important of these elements is human labor among a lot of other things. One widely used aphorism in the case of Latin America is that their "manana" culture will never let them be rich (Acemoglu, 2011) even though the widely accused Chinese culture and the Confucian values were proved very effective for the Chinese economy. Acemoglu insists that the extent to which people are able to cooperate and trust each other is what's important still not attributed to their religion, national ethics or values but is mostly the outcome of a country's institutions. The level of organization in a society and the efficiency of its institutions, only them, can guarantee better living conditions for people. When the institutions are absent should be founded, when already present should be either reformed or shut down. And since the country under examination here belongs to the developed part of the world where well established institutions are already present, then what remains to be seen is what went completely wrong. 


\section{Review of Literature}

After a long period of negligence, the issue of the economic value of education resurfaced when Theodore Schultz (1963), elaborating on the economic value of education together with Gary Becker(1964) and the work of Jacob Mincer $(1958,1962)$ provided a basis and offered a motive for the beginning of the subsequent major research efforts for the creation of human capital. In the following decades, from 1970 and on, research focused primarily on the relationship between education and income.

Despite the fact that research in the field of Economics of education is widespread and very popular among developed countries, the current study is trying to cover this gap in the literature, consisting one of the very few, if not the only doctoral dissertation in Greece in the field of Economics of Education, as this academic field is still at a very early stage. The goal of this thesis is to carefully report, examine and understand the individual choices for education, and their implications in the country's economic growth. Beyond the listing and analysis of the educational preferences and their fiscal outcomes, a large part of this study is focusing on the econometric estimation and empirical analysis of the data, with the most appropriate and up to date statistical methods suggested by the international literature. More specifically, the contribution of this study relies on the examination of the Greek economy for the period 1960-2011, covering also the period of the last global financial crisis of 2007/2008 which arouses big public interest, the economic and monetary union of Greece with the EU in 2002, and a number of other incidents. The main interest of this research is to unfold the relationship between education and economic growth, and extract useful conclusions and policy suggestions concerning the macroeconomic problems of the country, in order to contribute to the country's solid economic growth from now on.

\section{Data and Methodology}

At this point, the results of the linear and Non-linear Granger Causality tests are highlighted followed by the data variables and the data sources. The techniques that are being used will be further analyzed.

\subsection{Data Description.}

The empirical investigation has been carried out in the case of Greek economy, covering the period 1960-2012. The present study uses secondary data collected from the Greek Statistical Yearbook and the Greek Statistics of Education (several volumes). The variables used are Gross Domestic Product (GDP) and GDP per capita in euro and current prices, collected through Ameco (European database), total enrollments in preschool (PRE), primary (P), secondary (S) and higher education $(\mathrm{H})$, and Public Expenditures on Education (EDEX) in current prices taken from the Greek Statistics Bureau (ELSTAT).

Our original observations are 52, which is a size of sample that allows for Linear Granger tests to obtain results from. But traditional parametric tests for Granger causality with linear autoregressive models have reached a mature status, and have become "part of the standard toolbox of economists". Recent literature shows a preference in non parametric tests, against both linear and non linear Granger causality testing, taking into account the ever cheaper computational power. But the fact that we wanted to provide a less filtered result was the driver for using, not only constant prices but also, non-parametric and non-linear models to capture certain kinds of non-linear causal relations. As Granger (1989) also argues, univariate and multivariate non-linear models represent the proper way to model a real world "that is almost certainly non-linear. 
The scarcity of the data collected, the difficulty to gather more annual data and go further into the past, and the fact that the non-linear method used required a size bigger than ours, was the reason that our original sample was processed through interpolation method.

208 observations were uniformly used throughout the study.

\subsection{Empirical Methodology}

This section discusses the definitions of the Pairwise Linear and Non-linear Granger causality.

\subsubsection{Pairwise Linear Granger causality test}

We follow a methodology of three steps. First, we perform stationarity tests for all the variables involved. Depending on whether our variables are stationary or not, we proceed with integration, taking the first-differences for the non-stationary ones. Second, we run cointegration tests in order to see if there is any sign of any long-run relationship. Third, we run Linear Granger causality tests to detect the causality and the causal direction among our variables. A time-series $\mathrm{x}$ causes another time series $y$ in the Granger sense if the present value of y can be better predicted using past values of $\mathrm{x}$ than by not doing so. We also include past values of $\mathrm{y}$. In mathematical terms, $\mathrm{x}$ is said to cause y provided some ${ }^{C_{0}}$ term is non-zero in the full regression equation:

$$
\begin{aligned}
& y_{t}=\delta_{0}+\sum_{i=1}^{r} \alpha_{i} y_{t-i}+\sum_{j-1}^{s} \beta_{j} x_{t-j}+\varepsilon_{t} \\
& x_{t}=c_{0}+\sum_{i=1}^{r} \alpha_{i} x_{t-i}+\sum_{j=1}^{s} \beta_{j} y_{t-j}+\mu_{t}
\end{aligned}
$$

Errors are calculated by F-statistics.

\subsubsection{Non-linear Granger causality test}

A nonparametric statistical model is being used to cover the limitations of the linear approach to causality, concerning its weakness to detect certain kinds of non-linear causal relations.

In this study we apply the nonparametric Diks-Panchenko (2006) causality test, instead of a of "Baek and Brock (1992)" modified Hiemstra-Jones (1994) test. Diks and Panchenko (2006) argued that the Hiemstra-Jones test of non-linear causality may be inconsistent due to a bias, which cannot be removed simply by choosing a smaller bandwidth in the Hiemstra-Jones test statistic i.e., the Hiemstra and Jones test has serious size distortion problems and the results can be spurious. The new nonparametric Granger causality test proposed by Diks and Panchenko (2006) reduces the bias and lessens the risk of over-rejection of the null hypothesis.

Based on asymptotic theory Diks and Panchenko let the bandwidth be chosen upon and instructed by the sample size. This can be done by letting the bandwidth tend to zero at appropriate rates.

\section{Empirical Results and Analysis}

\subsection{Results of the Linear Granger causality tests}

The main results of the linear Granger causality tests are presented in Table1. The causal flow is indicated by the arrows in column 1. Column 2indicates the statistics for the null hypothesis of no causality .

After having run the Trace and Eigenvalue statistic, which have indicated the existence of one cointegrating vector, at least, we take the first differences and run the linear Granger causality tests. 
It can be seen from this table that

\begin{tabular}{|c|c|c|}
\hline LINEAR GRANGER CAUS & & \\
\hline $\begin{array}{l}\text { Null Hypothesis: } \\
\text { "x does not Granger cause y" }\end{array}$ & F-Statistic & Prob. \\
\hline GDP $\rightarrow$ EDEX & 6.03 & 0.0029 \\
\hline $\mathrm{EDEX} \rightarrow \mathrm{GDP}$ & 0.02 & 0.97 \\
\hline $\mathrm{PRE} \rightarrow \mathrm{EDEX}$ & 6.61 & 0.0017 \\
\hline $\mathrm{EDEX} \rightarrow \mathrm{PRE}$ & 20.19 & 0.00000001 \\
\hline HIGHER $\rightarrow$ GDP & 2.27 & 0.105 \\
\hline GDP $\rightarrow$ HIGHER & 0.549 & 0.578 \\
\hline GDP $\rightarrow$ SECONDARY & 11.52 & 0.00002 \\
\hline SECONDARY $\rightarrow$ GDP & 11.37 & 0.00002 \\
\hline ELEM $\rightarrow$ EDEX & 0.50 & 0.60 \\
\hline $\mathrm{EDEX} \rightarrow \mathrm{ELEM}$ & 1.00 & 0.36 \\
\hline SECONDARY $\rightarrow$ HIGHER & 0.72 & 0.48 \\
\hline HIGHER $\rightarrow$ SECONDARY & 4.02 & 0.01 \\
\hline $\mathrm{PRE} \rightarrow \mathrm{GDP}$ & 1.93 & 0.14 \\
\hline $\mathrm{GDP} \rightarrow \mathrm{PRE}$ & 1.21 & 0.29 \\
\hline
\end{tabular}

It is very interesting to denote the effect that Secondary education enrollments have on GDP per capita growth and vice versa. Also the causality running from Higher to Secondary education enrollments is the so called "opportunity cost" that is so often being mentioned.

\subsection{Results of the nonlinear Granger Causality}

\begin{tabular}{|c|c|c|}
\hline \multicolumn{3}{|c|}{ 1. Non linear Granger Causality Test (Asymptotic) Asymmetric } \\
\hline $\mathrm{n}=207$ & $\begin{array}{c}\text { Embed. Dimension: } 3 \\
\text { Bandwidwth:0.2 }\end{array}$ & \\
\hline Null Hypothesis: $\mathbf{x}$ does not cause $\mathbf{y}$ & T statistics & p-value \\
\hline $\mathrm{EDEX} \rightarrow \mathrm{PRE}$ & 2.558 & $\underline{0.005 * * * *}$ \\
\hline PRE $\rightarrow$ EDEX & 1.048 & $0.147 *$ \\
\hline HIGHER $\rightarrow$ GDP & 1.508 & $0.065^{* *}$ \\
\hline $\mathrm{GDP} \rightarrow \mathrm{HIGHER}$ & 1.391 & $0.082^{* *}$ \\
\hline $\mathrm{EDEX} \rightarrow \mathrm{GDP}$ & 1.333 & $0.091^{* *}$ \\
\hline GDP $\rightarrow$ EDEX & 1.124 & $0.130 *$ \\
\hline EDEX $\rightarrow$ HIGHER & 1.423 & $0.074^{* *}$ \\
\hline HIGHER $\rightarrow$ EDEX & 0.854 & $0.196 *$ \\
\hline EDEX $\rightarrow$ SECONDARY & 2.029 & $0.021 * * *$ \\
\hline SECONDARY $\rightarrow$ EDEX & 0.752 & $0.226 *$ \\
\hline $\mathrm{GDP} \rightarrow \mathrm{PRE}$ & 2.601 & $0.00464 * * * *$ \\
\hline PRE $\rightarrow$ GDP & 1.266 & $0.107 *$ \\
\hline GDP $\rightarrow$ ELEMENTARY & 1.598 & $0.054 * * *$ \\
\hline ELEMENTARY $\rightarrow$ GDP & 1.300 & $\overline{0.097 * *}$ \\
\hline GDP $\rightarrow$ SECONDARY & 2.128 & $0.016^{* * *}$ \\
\hline SECONDARY $\rightarrow$ GDP & 1.321 & $0.093 * *$ \\
\hline SECONDARY $\rightarrow$ HIGHER & 1.498 & $0.067 * *$ \\
\hline HIGHER $\rightarrow$ SECONDARY & 1.412 & $0.078^{* *}$ \\
\hline
\end{tabular}


There is very weak evidence for the existence of non-linear causality from preschool enrollments to economic growth. Still there is no evidence of unidirectional nonlinear causal relation between preschool and education expenditure growth as well. Also the causality running from university and high school enrollments seem to have little or no effect to investments in education. Economic growth though seems to provoke a rather significant causal rise to higher education enrollments, while the other way around is a strong causal relationship itself too.

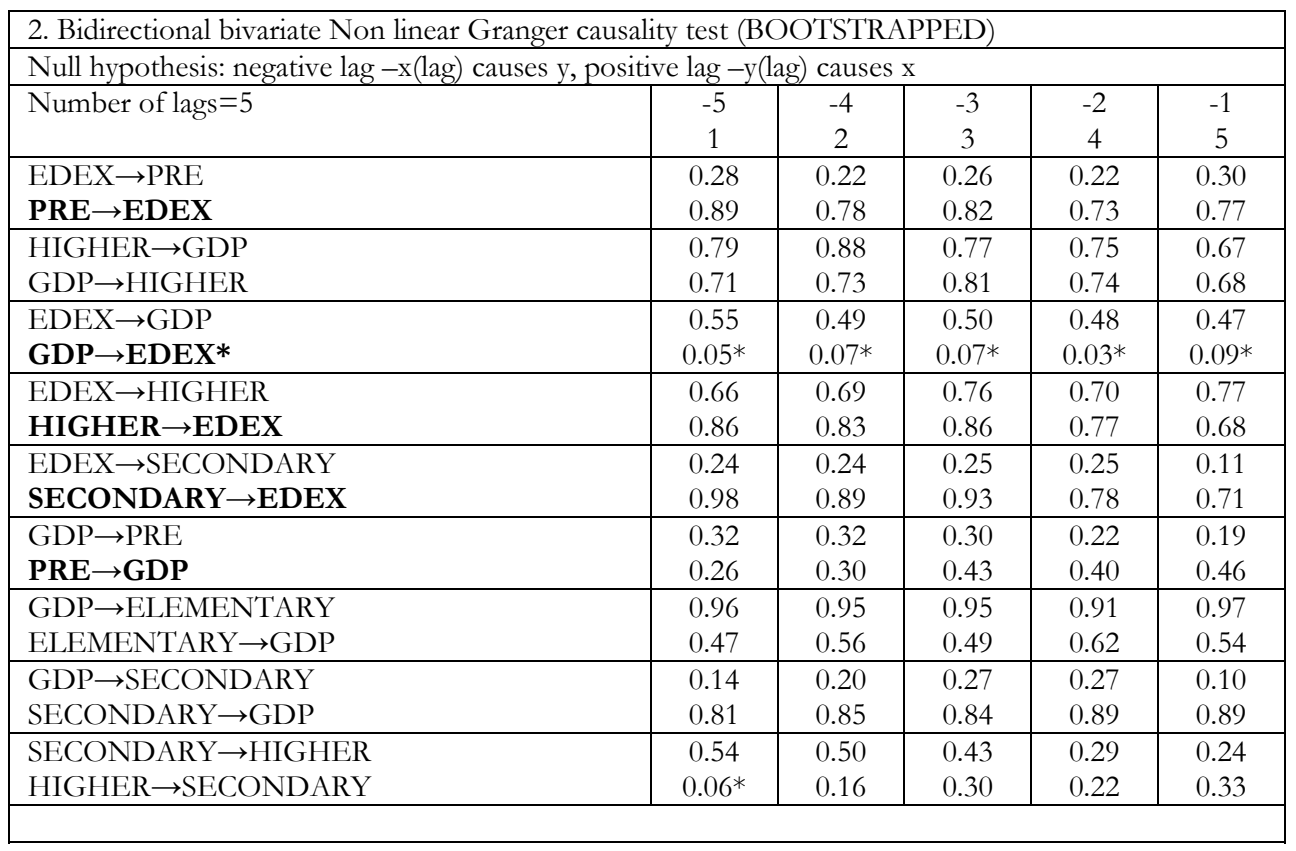

The results obtained from the test indicate evidence of bidirectional non-linear causality running from all of the afore mentioned variables. This does not stand for what Economic growth does to Education expenditures.

\section{Conclusions}

In this paper we investigated the existence of non-linear causality between the educational expansion and expenditures and the country's economic growth for the period 1960 to 2012 in Greece.

It can be seen that the results of the non-linear Granger causality are quite similar to the ones derived by the linear Granger causality tests. The causality between Economic growth and secondary education is not validated by the nonlinear Granger causality tests, which can be regarded as positive sign for growth. Today, a growing number of high school graduates in Greece, still pursue further with their studies.

By applying the Nonlinear Granger causality test we also confirmed the passive role of Educational expenditures towards economic growth.

Future research should be extended to include more macroeconomic variables series, and we would extract useful information if applied to different economies. In such a way, we could examine the role of the macroeconomic effect of education and, also the role of the different economies in the fast-growing knowledge economy. 


\section{References}

Acemoglu D. Angrist J. (1999) How Large are the Social Returns to Education? Evidence from Compulsory Schooling Laws. NBER Working Paper, 7444.

Andrada M.J. and Galassi G.L. (2009) Education, labor market and life quality: A quantitative approach based on Mincer Equations. Centro de Estudios Avanzados (CEA), Cordoba, UNC Consejo Nacional de Investigaciones Cient cas y Tecnicas (CONICET).August 2009

Angrist J.D. and Krueger A. B.(1991) Does Compulsory School Attendance Affect Schooling and Earnings? The Quarterly Journal of Economics, 106, 979-1014.

Asteriou D. and Agiomirgianakis G.M. (2001). Human capital growth. Time series evidence from Greece. Journal of Policy Modeling, 23, 481-489.

Asteriou D. and Siriopoulos C. (1997) Can educational expansion function as a "seed" of economic development in developing countries? City University. Department of Economics and Applied Econometric Research Unit. Discussion Paper Series, 68.

Baek, E. and Brock, W., 1992. A general test for nonlinear Granger causality: Bivariate Paper, Iowa State University and University of Wisconsin, Madison, WI.

model, Working

Becker, G. S. (1964): Human Capital: A Theoretical and Empirical Analysis, with Special

Reference to Education. Columbia University Press, New York.

Becker, G. S. (1967): Human Capital and the Personal Distribution of income. Ann Arbor. University of Michigan Press. Michigan.

Card D. (1999) The causal effect of education on earnings. Handbook of Labor Economics In Ashenfelter O. Card D. (Eds), Handbook of Labor Economics, vol. 3. Elsevier: London; 1999. P. 1801-1863.

Card D. (2001)Estimating the Return to Schooling: Progress on Some Persistent Econometric Problems, Econometrica, 69, 1127-1160.

Card D., Lemieux T. (2000): Dropout and Enrollment Trends in the Post-War Period: What Went Wrong in the 1970s? NBER Working Paper, 7658.

Cameron S.V. and Heckman J.J. (1998). Life Cycle Schooling and Dynamic Selection Bias: Models and Evidence for Five Cohorts of American Males. The Journal of Political Economy, 106, 262-333.

Dickey, A. and Fuller, W.A., 1979. Distribution of the estimators for autoregressive time series without unit root, Journal of the American Statistical Association, Vol. 74, pp. 427-431.

Diks, C. and Panchenko, V., 2006. A new statistic and practical guidelines for nonparametric Granger causality testing. Journal of Economic Dynamics \& Control, Vol. 30, pp. 1647-1669.

Granger, C.W., 1969. Investigating causal relations by econometric models and cross-spectral methods, Econometrica, Vol. 37, pp. 424-438.

Hiemstra, C. and Jones, J., 1993. Monte Carlo results for a modified version of the Baek and Brock nonlinear Granger causality test, Working Paper, University of Strathclyde and Securities and Exchange Commission.

Hiemstra, C. and Jones, J., 1994. Testing for linear and nonlinear Granger causality in the stock price-volume relation. Journal of Finance, Vol. 49, pp. 1639-1664.

Hanushek, E.A., Woessmann L.(2007) The Role of School Improvement in Economic Development. World Bank Working Paper, 4122, Washington.

Hanushek, E.A., Woessmann L. (2009) Do Better Schools Lead to more Growth? Cognitive Skills, Economic Outcomes, and Causation. NBER Working Paper Series, 14633.

Hanushek, Woessmann (2011). The economics of International Differences in Educational Achievement. In Hanushek E. A. Welsch F. (Eds), Handbook of the economics of education vol. 3. Elsevier: London; 2011. P.

Harmon C. Walker I.(1995) Estimates of the Economic Return to Schooling for the United Kingdom, American Economic Review, 85, 1278-1286.

Heckman J. J. Stixrud J. and Urzua S. (2006) The Effects of Cognitive and Noncognitive Abilities on Labor Market Outcomes and Social Behavior. Research presented at the AEA annual meeting, Boston.

Heckman J.J. Vytlacil E. (1998) Instrumental Variables Methods for the Correlated Random Coefficient Model: Estimating the Average Rate of Return to Schooling When the Return is Correlated with Schooling. The Journal of Human Resources, 33, 974-987.

Heckman, J. J. Honore B. E. (1990). The Empirical Content of the Roy Model. Econometrica, 58, 11211149. 
Heckman J.J. Lochner J.L., Todd P.E. (2003) Fifty Years on Mincer Earnings Regressions. IZA, Bohn, Germany.

Heckman, J.J., Lochner, L.J. and Todd, P.E. (2006). Earnings Functions, Rates of Return and Treatment Effects: the Mincer equation and beyond. In: Hanushek E.A. Welch F. (Eds), Handbook of the economics of education, vol. 1. Elsevier: London; 2006. P. 307-451.

Lee L. F. (1978) Unionism and Wage Rates: a Simultaneous Equations Model with Qualitative and Limited Dependent Variables, Int. Econ. Rev., 19, 415-433.

Lianos T.P. et al. (2004). Foreign University Graduates in the Greek Labour Market: Employment, Salaries and Overeducation. Int. Journal of Fin. and Econ., 9, 151-164.

Mc Elroy M. B., Horney M. J. (1981) Nash -bargained household decisions: toward a generalization of the theory of demand. Int. Econ. Rev., 22, 333-349.

Meghir, C. and Palme M. (2005). Educational Reform, Ability, and Family Background. The American Economic Review, 95, 414-424.

Meghir C. and Rivkin (2011). Econometric methods for research in Education. In: Hanushek, Woessmann (Eds), Handbook of the economics of education, vol.3. Elsevier: London; 2011. p. 1-81.

Miller R. A. (1984) Job Matching and Occupational Choice. Journal of Political Economy, 92, 1086-1120.

Mincer, J. (1958). Investment in human capital and personal income distribution. Journal of Political Economy, 281-302.

Mincer, J. (1974). Schooling, Experience and Earnings, Columbia Un. Press, New York.

Mincer J. (1994) The production of human capital and the lifecycle of earnings: variations on a theme.NBER Working Paper, 4838.

Patrinos H.A. (1992) Higher education finance and economic inequality in Greece. Comparative Education Review, 36, pp. 298-308.

Patrinos H.A. (1995) Socioeconomic background, schooling, experience, ability and monetary rewards in Greece. Economics of Education Review, 14, pp. 85-91.

Polachek, S. W. (2003) Mincer's Overtaking Point and Lifecycle Earnings Distribution, IZA Working Paper, 865.

Psacharopoulos G. (2002) The Social Cost of an Outdated Law: Article 16 of the Greek Constitution. 19th Annual Conference European Association of Law and Economics Athens.

Psacharopoulos G. (1994) Returns to investment in education: A global update. World Development, 22, pp. 1325-1343.

Psacharopoulos G. Kanellopoulos C. (1997) Private Education Expenditure in a 'Free Education' Country: The Case of Greece. International Journal of Educational Development $17,73-81$.

Psacharopoulos G. Magoula T. (1999)Schooling and Monetary Rewards in Greece: An Overeducation False Alarm. Applied Economics, 1589-97.

Psacharopoulos G. Tsamadias K. (2001) Testing for Screening using Vocational skills: The Case of Greece's Technological Institutes. International Journal of Educational Planning and Administration, 15, 425-434.

Psacharopoulos G. and Papakonstantinou G.(2005). The real university cost in a "free" higher education country, Econ. of Ed. Rev., 24, 103-108.

Sala-i-Martin, X., 1997. I just ran two million regressions. American Economic Review, Vol. 87, pp. 178-183.

Willis R. J. and Rosen S. (1979) Education and Self-selection. Journal of Political Economy, 87, S7-S36. 